\title{
The IMF in Singapore: The Staging of a City
}

\author{
Yasmin Ibrahim
}

The mass protest at the Seattle summit of the World Trade Organization (WTO) in November 1999 and the subsequent anti-globalization protests around the world signify new forms of global movement against transnational capitalism (Deluca and Peeples 2002). Much has been written on global social movements, their mobilization strategies and interesting and innovative use of new media spaces (See Bove and Dufour 1999; Bircham and Charlton 2000; McMichael 2000; O’Brien et al. 2000; Kellner 2001). As Koopmans (2004:367-369) points out in 'the age of globalization direct engagement between protestors, authorities and publics have certainly not disappeared completely but they occur where the targets of claims are located; in national capitals, in seats of supranational institutions such as Brussels and Geneva or New York or where state leaders gather for international summits such as Seattle, Davos or Genoa. The convening of global summits in global cities has often set the stage for the activists to use the media as a global specter for performance, connectivity, interactivity and mobilization. In this sense, it is no longer the bystanding or co-present public that matter but people who watch at home.'

Smith (2001:1-2) posits that the Seattle protests 'challenge our understanding of state-social movement relations because they demonstrate how global-level politics affect a wide range of local and national actors.' More succinctly, he considers the political processes forged in national terrains of struggle which can challenge the transnational structure of capital. Here the concept of the local and global are entwined through the common objectives of global struggle against neo-liberalism. The local, national and global are bound through this thread which can enhance the bonds of a global civil society (Hubbard and Miller 2005; Mayo 2005; Tarrow and Della Porta 2005).

In situating TV screens as the contemporary shape of the public sphere, Deluca and Peeples (2002:126-127) observe that the 'WTO summit in Seattle was designed by the Clinton administration to be an image event designed for mass dissemination.' Organizers anticipated that tens of thousands of people would converge on downtown Seattle and 'transform it into a festival of resistance with mass nonviolent direct action, marches, street theatre, music and celebration.' The intrusion of the global media into this theatre of protest creates a visuality which lends global social movements new forms of agency enabling them to raise and legitimise global issues of injustice ranging from poverty to environmental concerns.

In the same vein, the International Monetary Fund (IMF) and World Bank (WB) meetings in Singapore in 2006 were designed to be an image event by the Singapore government; not necessarily for the theatre of protest that would descend on the island but for the profile it would offer in terms of global media attention and the economic benefits in terms of positioning the island as a venue for world-class events. While the planned high-profile meetings drew Singapore into the spotlight in the months leading to the event, the tiny island courted the attention of the world media for different reasons. The culture and ritual of protests which surrounds meetings like the IMF, G8 and WB were deemed as antithetical to the political culture of the island. What was to be a showcase media event for Singapore created a ripple of discontent through global civil society organizations, interest groups and the world press due to the government's decision to blacklist 27 activists and to restrict the activities through stringent rules. The culture of protest that accompanies such high-profile events was viewed as a security issue by a state known for its high levels of social control.

This paper discusses the mediatized nature of the event which drew local political governance into global 
scrutiny and analyses the ways in which the Internet was used to engage, publicize and mobilize dissent against the authorities in Singapore. In capturing the tension between the local and the global, the paper highlights the tensions that can emerge in local spaces which disrupt the agency of global social movements. In examining the dialectics between local politics and global social movements, the paper examines the spatial construction of the nationstate of Singapore through its ideological discourse of survival where the city state is constantly re-imagined and constructed through this discursive sphere. This discursive sphere is mediated by both the need to attract global capital and to appropriate technology as a tool to re-invent the economy, governance and society. Douglas Kellner (2001) employs the term 'technopolitics' to convey how significant political struggles against globalization today are mediated by the use of new technologies such as computers and the Internet to advance political goals. This paper contends that 'technopolitics' can narrate the city state in a contrasting light, highlighting the resistance and subcultures that emerge in the electronic terrain.

\section{| Politics of Re-Invention}

This paper theorizes the city state of Singapore as a discursive space that has been constantly re-invented through the overarching discourses of survival and crises. The need for excellence and international recognition is often narrated through the pathos of economic revivalism where the re-invention of the city's identity for economic survival through the years has been an integral part of its modern imagination. The origin of independent Singapore is part of a narrative that is not only contentious in its historical representation but also subject to constant negotiation (Lim 2001). This constant negotiation often attempts to incorporate dialectical ideological strands such as Confucian teachings and essentialist Asian values, while facilitating the movement and embedding of global capital and transnational corporations in the island state. From the establishment of Singapore's self-government from the British in 1959, its merger with Malaya in 1963, and its subsequent expulsion from Malaysia and independence in 1965, the city state has been narrated through the discourses of survival and crises with the emphasis on economic progress and expediency.

The city state's successful post-independence economic development from 1965 to the 1990s has been described as a process of 'disciplinary modernization', one which has been presided over by the leadership of the People's Action Party (PAP) which has been in power since 1959 (Wee 2001:988). Wee argues that Singapore's small size allowed the PAP to exercise a great deal of social control and to orchestrate its multicultural society in accordance to the needs of multinational capital. The process of facilitating industrialization and the attraction of global capital required the mobilization and disciplining of a large proportion of the population through a combined scheme of mass education, labour unions and labour development programs (Lim 2001). The homogenizing tendencies of industrialization and its intimate link with nation-building mean that the conception of the nation has been articulated through the processes of industrialization (Gellner 1983). In Singapore, the identity of the city state is negotiated through the construct of nation-building and is also shaped by the vagaries of global capital.

Alwyn Lim (2001) argues that the overarching ideology of survival and crises employed by the PAP should be situated within the wider processes of postcoloniality, postmodernity, globalization and technocapitalism. Lim (2001) further contends that the rhetoric of a utopian technological society has occupied a central strand in the politics of Singapore as evident in the 'Intelligent Island and 'knowledge-based economy' discourses. These discourses have become common tropes through which the image of Singapore and its body social have been articulated since the 1990s. Here Douglas Kellner's (1989:178) technocapitalism conveys not only the physical characteristics and networks that rely on Information and Communication Technologies (ICTs) but also the social relations mediated by and through the use of technology which enable the simultaneous deterritorialization and reterritorialization of economic markets as well as cultures (cf. Lim 2001:178).

As Kahn and Kellner (2003:49) postulate, our 'contemporary landscapes represent a "postmodern adventure" where traditional forms of culture and politics are being resurrected, imploded into and combined with entirely new cultural and political modes in a global media culture that is becoming increasingly dominated by the corporate forces of science, technology and capital'. Equally, the re-imagination of Singapore's post-colonial condition through the re-configuration of her economy and the mass appropriation of information and communications technology are key elements in constructing a discursive reality of the city state which is constantly reminded to be ready to adapt to the needs of global capital and transnational corporations (Lim 2001). 


\section{The IMF in Singapore}

When Singapore hosted the IMF and World Bank annual meeting in September 2006, it was billed to showcase the efficient management of a world event by a tiny island state. The government invested approximately $\$ 85 \mathrm{~m}$ to host the September 2006 meetings of the IMF and WB basing 16,000 delegates as a captive audience to promote the Singapore's finance and tourism industries (Rodan 2006). The event however became a spectre for contention between state ideology and the global entities of the the IMF, World Bank and various international civil society organizations. Over the years, the IMF and WB have endeavoured to project these conferences as a stage where civil society organizations, non-government organizations and charitable institutions are integrated into the event both as insiders who contribute to the consultation process and outsiders who manifestly protest against the agenda and actions of the IMF and the World Bank. It represents a reflexive post-modern capitalism which can accommodate dissident voices while catering to its own intrinsic logic.

The annual meetings of the Bank and the IMF usually draw large gatherings of financial representatives of governments, and the policies of these two international financial institutions are discussed as global initiatives. These discussions can range from poverty reduction to international finance. Every three years the meetings are held outside Washington and previous venues have included Prague, Hong Kong, Bangkok, Berlin, Manila, Nairobi and Rio de Janeiro (Macan-Markar 2006). As such, accredited organizations are invited to the summit to voice their concerns and to protest against the agenda of these global entities. The summits tend to be volatile as tensions can run high. When the meetings were held in Hong Kong in 2005, the government used tear gas to disperse crowds. It also arrested more than 1,000 people. Similarly, 600 were injured during the IMF meeting in Prague in 2000 after cobblestones were pulled from the streets and flung at the police. Protests held outside the conference venue have helped NGOs and activists from the developing and developed world to articulate and publicize concerns that matter to the world's poor which the two institutions may ignore or not give a serious hearing to. They have also helped frame the debates between the powerful within the conference halls and the powerless on the streets (Macan-Markar 2006). Civil society organisations have also been critical of the IMF's and WB's recent preference for remote or authoritarian countries to host these events (Burton 2006).

The notion of hosting a demonstration-ridden summit is antithetical to Singapore's political culture, which uses legislation to discourage protests. Singapore's laws prohibit public assembly of more than four people without a police permit, and those found guilty of unlawful assembly can be fined up to $\$ \$ 1,000$. The government's official discourse consistently cites the race riots of 1964 as a political and cultural justification for such prohibitions. In view of this, the IMF/WB summit became a media spectacle in the months and weeks leading up to the summit as reports around the world focused on the Singapore government's bid to stifle protest by citing international and local safety and security concerns. On 12th September 2006, the government announced its decision to blacklist 27 activists. This led to 12 civil society groups immediately boycotting the IMF/WB meeting, followed by over 160 Nongovernment Organizations (NGOs) in the next few days. The city state was described as resorting to 'draconian security measures' and not 'respecting civil and human rights' (Meng 2006). Garry Rodan (2006) argues that economic globalization is contributing to a growing scrutiny of and challenge to Singapore's governance system and that the IMF/WB summit re-opened some of these debates. He cites the example of EnerNorth Industries, a Toronto-based oil and natural gas company which is requesting a review of a ruling which is pending before the Canadian Supreme court. EnerNorth is seeking to overturn a decision by the Ontario Superior Court of Justice to abide by a Singapore High Court ruling. Enernorth's appeal centres round the contention that 'Singapore is ruled by a small oligarchy who control all facets of the Singapore state, including the judiciary, which is utterly politicized' (cf. Rodan 2006).

These media discourses construct the city space of Singapore as a fortress inaccessible to civil and civic engagement and as an immature polity which has not developed in tandem with its economic progress. This prompted civil society organizations around the world to protest against the conference in Singapore, which led the IMF and World Bank to move their activities to the nearby Indonesian island of Batam, as Indonesia is known to have a more robust civil society culture than the highly-governed state of Singapore. The Internet played a significant role in enabling global civil society organizations to publicize their objections and to co-ordinate their activities with other organizations.

\section{| The City as a Myth Space}

International events are often an opportunity to showcase a city. The coding of spaces is vital to the cultural 
politics of capitalism which transforms the city space into a performative arena. The continuous ranking and typographies of cities and places synthetically construct and invent them in different ways which may at times be incompatible with each other. For example, Singapore was ranked second after Hong Kong in terms of economic freedom by the Heritage Foundation and the best place for Asians to live in a survey released in April 2006 by human resource consultancy ECA International (Burton 2006). Contrastingly, Singapore ranks 140th out of 167 countries for press freedom in 2006, polling lower than Afghanistan (Reporters Without Borders).

Spatial practice defines place and consequently space is 'made with the visible in mind; the visibility of people and things and whatever is contained within them' (Lefebvre 1991:288). The social activities of its inhabitants are just as crucial as the stationary physical parts, as people are not simply observers of this spectacle, but are themselves part of it (Lynch 1960:2). As such, social activities are entwined with space as the former creates the latter (Lynch 1960; Lefebvre 1991; Tschumi 1996). Places can thus be symbolically constructed as desirable or undesirable, benevolent or malevolent, sanctioned or forbidden to particular groups (Lefebvre 1991). In this sense, both sanctioned and forbidden practices and discourses construct the city space of Singapore as a place of double articulation manifest through discourses of officialdom and sanctioned practices as well as muted yet present (via new media technologies) activities which are rigorously controlled and disciplined through the entire era of nation building and beyond.

Representations of space tend to define and order spatial realities. The city space as an imagined geography mediates the politics of the island as it signifies a myth-making and transformative space. Its visual presence is a testimony to the island's progress since independence. It is symbolic of modernity and independence and hence deeply embedded into the party politics of the PAP which has ruled the nation state for more than 40 years. The city commemorates the success of the PAP's economic policies and as a visual space it narrates a historicity which portrays the PAP as the main protagonist in the transformation of Singapore into a metropolis from a fishing village. Notions of myth and space are tightly intertwined and often the physical transformation is narrated through myth which forms part of the wider belief system in a society. History becomes a narrative accomplice where it moves events temporally to create and transform the nation as a myth of those in power.

The urban space as a myth space signifies the selective re-telling of the past to enforce the present as a glorious achievement. The city state of Singapore as such acquires a chameleon-like persona often adopting or even adapting the approved and imposed cultural facades of the government machinery while rejecting or synthetically re-inventing the practices and street life which have been banished and perceived as incongruous to the images of the newlyformed city. The street theatres (wayangs), the night bazaars (Pasar Malam) or even the hawkers who plied their trade in the city are banished images which can be resurrected at will in sanitized and permitted areas with a licence or permit from the government. The city is an ordered space for the government's vision and a space where ideological and material practices coincide.

Urban space is political and is a domain for re-imagining the nation through its economic development. The constant texturization of the urban landscape through skyscrapers, modern technology and a high level of governance manufactures a space of Virilion hypermodernity characterised by efficiency and speed through the appropriation of state-of-the-art technology. This form of technology-driven change fabricates an accelerated modernity where electronic grids, digital sensors, and infra-red apparatuses guard, monitor and create a visual order. Speed is perceived as pivotal to transportation and communication and, therefore, to flows of capital (Virilio 1986). For Virilio, this accelerated modernity is one in which image and vision (both its appearance and disappearance) craft modernity as an accelerated coagulation of form and speed. The city as a conveyor belt for speed and change constantly alters the landscape creating a new urban visuality which leverages on the appearance and disappearance of images. Here old landscapes make way for the new in the name of progress and economic development, thus confining history into a hermeneutically-sealed space where its interpretation is a tool for the ideological hegemony of the present.

As such, the myth of the urban constructs capitalism and capital flows as a panacea for economic regeneration and the population as the necessary labour which must be orchestrated according to the demands of capital. The urban space is a scripted place where the culture of capitalism is reified and represents a new form of independence as well as dependence in the global world and market system. The urban space as such celebrates commerce, industry and entrepreneurship where the ethics of capital are accommodated and implicitly embraced.

This has meant the 'sanitizing' of urban space in Singapore through the selective retention of the old and a constant re-making of the urban to suit the needs of capital. The sanitization of urban spaces has seen the imposition of fines for spitting, littering and chewing gum. The constant renewal and purification of the city has taken various avatars over the decades and is characteristic of the transformative potential intrinsic in the urban 
space. It is malleable to the political cartographies where technocrats can invent and re-invent space in a range of ways constructing Singapore in various guises from a regional financial and information technology hub to a centre for the arts and media. Here, manipulating the images of the city is an important aspect of urban entrepreneurship (Dobers 2003) where the city is manufactured through an abundance of images and representations (Hubbard and Hall 1996).

\section{Texturing the City through Control}

The city as an arena for entrepreneurship may be socially constructed and may constitute a space for introducing new forms of re-imagining and thinking as well as for reorganizing entrenched practices while creating new ones to accommodate a range of goals beyond those of simple commerce and economic drive (Stayaert and Katz 2004). Inimically, Hall and Hubbard (1998) contend that the emergence of urban entrepreneurialism marks a shift from urban government to urban governance which is characterized as both organizational and institutional in its execution. The entrepreneurial landscape of the city, catering for both the real and imaginary is inevitably ideologically charged (Hall and Hubbard 1996:163).

Cherian George (2001) labels the city state of Singapore as an 'air-conditioned' nation to highlight the degrees of control imposed on the state space where a whole host of incentives and disincentives are often packaged to extract compliance from the population. The bubble of air-conditioning represents a climate of control wielded by the ruling party and its ability to micro-manage the population from eugenics to speaking proper grammatical English to enhance trade and commerce in the country. According to Stan Cohen (1979:36) the emergence of the punitive city is characterized by the blurring of boundaries of control manifest in the widening nets of regulation in a manner that increase visibility and hence the theatricality of social control. Thus, highly repetitive acts that monitor, censor as well as promote behaviour in the city reflect and reinforce particular kinds of social space (Lefebvre 1991:75). While sets of meanings of the social imagination are conceptualized in symbolic languages these meanings are materialized and become real in all sorts of spatial and social practices from urban design to housing policy (Zukin et al. 1998:629). Edward Soja (2000) employs the term 'Postmetropolis' to refer to a transition from what has conventionally been the modern metropolis to something significantly different. In the case of Singapore, the imposition of authority, ideology and morality on a space of accelerated modernity has given rise to an orchestrated visual order which is plagued by dialectical struggles between social, economic and ideological forces which potentially threaten this visual coherence.

The city state of Singapore extols order, and the curbing of trade unions, civil liberties, civil society organizations and opposition politics has often assumed the rhetoric of catering to the demands of capital and the need to be competitive on the economic stage. It has also nullified Huntington's (1991) hypothesis that economic progress will eventually ensure human rights and civil liberties. Instead, countries like Singapore champion the banner of 'Asian democracy' which canvasses for a brand of democracy which is sympathetic to the cultural uniqueness of Asian nations by constructing an essentialist ideal of Asian values. These polities endorse a paternalistic form of governance which is pedantic and top-down in its approach, and often contradictory to the spirit of entrepreneurship demanded by capitalism. The monopolization of the domestic media and the constant silencing of the foreign media as well as political opposition further augment the construction of the city state as a hegemonic discursive space.

According to Deleuze (1997), control societies have taken over from discipline societies and thus the need for this ideological control manifests in various dimensions. Deleuze (1997) further terms marketing as an instrument of social control where the entrepreneurial city engages in new urban politics (Hall and Hubbard 1998) to pitch itself in the global market place for location marketing. Delueze (1997) constructs entrepreneurial politics as one which constantly demands urban space to behave entrepreneurially to lure flows of transnational capital.

Castells (1996:420) contends that because function and power in our society are organized in the space of flows, the structural domination of its logic essentially alters the meaning and dynamic of places. In tandem with this, John Urry (2000:140) propounds that places can be 'loosely understood as multiplex; as a set of spaces where ranges of relational networks and flows coalesce, interconnect and fragment.' As such the city space of Singapore is an ideological space carved through the trajectories of nation-building projects and a confluence of competing ideologies which construct the West as decadent and culturally incongruous to the East and the latter as a vulnerable construct which can be corrupted by these cultural flows. Economic development and progress are placed very high 
on the political agenda while the liberal democratic ideals of a free press and human rights are seen as antithetical to the cultural ethos of the island. But the facilitation of capital and new forms of enterprise can further compound these debates. The granting of a gambling licence for a downtown casino, despite objections from the citizens, is a case in point.

Visually, the city of Singapore parades the culture of capitalism while political forces embrace the need to retain the 'Asianness' of the city through its cultural politics which suppresses pluralism and diversity. Ernest Laclau (cf. Coleman 2005) conceives cities as having a 'surplus of meaning' as they become spaces contaminated by different cultures, forces, desires and needs. These surpluses (of meaning) find expression in different ways in the cityscape of Singapore. The city as a repository for doubleness, between the official and the banished, between rhetoric and practice, and between the visible and the covert becomes a site of contestation and ideological struggles, as was evident at the IMF/WB event.

\section{| Constructing the City through Discourse}

In hosting the summit, the Singapore government initially objected to various entities protesting in the city. It couched much of its objection to the theatre of protest that accompanies these summits on the premise it would threaten security in the nation state. With the government's ban on outdoor protests, groups accredited to the IMF and World Bank were only allowed to hold demonstrations in an eight-by-eight meter designated area. All other protests were required to obtain a police licence. According to Ruki Fernando, a spokesman for the Asian Forum for Human Rights and Development, a Bangkok-based human rights group, this restricted activities such as cultural dances and street theatre which requires large spaces (Burton 2006). In the lead up to the summit media reports around the world focused on how the Singapore government interrogated, detained and denied entry to various civil society representatives. Senior Minister, Goh Chok Tong, defended the decision to ban outdoor protests, saying the government would be seen as practicing double standards if it relaxed restrictions, 'We have very strict rules for our own locals and we can't have two standards, because otherwise we'll be in deep political trouble with our citizens.'[1] Discourses in society, in this sense, can be performative as well as descriptive because they are embedded in material and social practices, codes of behavior, institutions and constructed environments (Sayer 2000:44).

Prior to the IMF/WB summit the government had warned that it was prepared to cane or imprison protesters who commit violent crimes during the event. Singapore's actions invited the wrath of the then World Bank chief, Paul Wolfowitz who described the state as 'authoritarian and short-sighted' and argued that 'at the stage of success they have reached, they would do much better for themselves with a more visionary approach to the process. Enormous damage has been done and a lot of that damage is done to Singapore and self-inflicted.'[2] Singapore in response declared that it was duty-bound to 'take all necessary measures for the safe passage of all persons in and out of Singapore and for their personal security and the safety of their property and the property of the Organizations and delegations', particularly 'in view of the prevailing international security environment.'[3]

The social space of Singapore, weeks preceding the meeting was primarily observed and discussed on the foil of security and order and often visual order is imposed through security measures (Davis 1990; Hall and Hubbard 1998). The city space in Singapore is a space of high-level governance where social activities are mediated to regulate appearance and maintain control. Coleman (2005) points out that the development of entrepreneurial surveillance practices is increasingly geared to the monitoring of the performative space and its potential disruption and hence the social construction of this space is embroiled with moralizing discourses that constitute what spaces are and for whom they are intended.

Following criticism from Mr. Wolfowitz, Singapore relaxed its ban on the activists, allowing 22 out of the 27 (on an immigration blacklist) into the country. [4] While bowing to the pressure exerted by global entities, the authorities nevertheless wanted to ensure that the event would remain a visual spectacle for the locals and not be seen as an opportunity to protest. Two weeks ahead of the IMF/WB meeting, police issued a warning that security forces would not be averse to the use of firearms against protestors who threatened the life or health of others. More than 10,000 police officers joined forces with the military and other agencies to ensure the largest international event ever to be held in Singapore proceeded without a problem.[5]

According to Reporters without Borders, 'The two international bodies could hardly have made a worse choice of country in which to hold an international conference,' as 'press freedom should be one of the key elements of 
an open and dynamic economy'.[6] The blocking of global activism was happening in tandem with various internal political events which portrayed the city state in a negative light. These included the ex-prime minister Lee Kuan Yew and his son the current prime minister, launching a lawsuit against Far Eastern Economic Review (FEER), the defamation suit against the opposition politician Chee Soon Juan and the trial against two Falun Gong protesters. Additionally in its on-going endeavor to curb the voice of the foreign press, the Singapore government had ordered five foreign publications to post bonds of $\$ \$ 200,000$ and appoint representatives in Singapore.[7] The bonds would serve as a security measure in any future government lawsuit for alleged defamation where the publishers were not based in Singapore but were distributing their material locally.

\section{The City and Resistance}

This paper argues that the city space of Singapore can equally be narrated and constructed through the various activities which were blocked and thwarted by the authorities. With the stringent regulations on public gathering and the legalities surrounding them, much of the communal agency with regard to political expression and political activism has migrated to online spaces. The online spaces of the city compared to the offline environment is a sphere that is manifestly reactive as well as constitutive of the displaced agency that has been denied in the physical spaces of the city. According to Douglas Kellner (2001), 'Technopolitics' makes possible the reconfiguring of politics by refocusing on the politics of everyday life and using the tools and techniques of new computer and communications technologies to expand the field and domain of politics. Kellner (2001) stresses the construction of situations, the use of technology, media of communication and cultural forms to promote a revolution of everyday life, and to increase the realm of freedom, community and empowerment. The forms of empowerment that can emerge from the coalescing of agency and technology in the electronic sphere can also signify new forms of narrating the nation space.

A number of writers have explored the Internet as a platform for activism (Kellner 2001; Kahn and Kellner 2003; Lovink 2002; Lubbers 2002; Meikle 2002; Mielke 2003). Tim Berners-Lee, creator of the World Wide Web (1999:182-183) stresses the concept of 'interactivity' as the ability for others to make their media interventions. Another concept that is relevant to using new media platforms in innovative ways is the term 'tactical media.' Tactical media refers to a critical usage and theorization of media practices that draws on all forms of old and new, both lucid and sophisticated media for achieving a variety of specific non-commercial goals and pushing all kinds of potentially subversive political issues (cf. Meikle 2003:7). As Lubbers (2002:13) observes, the key characteristics of tactical media are originality, playfulness, unexpectedness, smallness, speed, decisiveness, clarity and unstoppability.

Lovink (2002:271) points out that 'tactical media provides a tool for creating temporary alliances between hackers, artists, critics, journalists and activists.' Lovink qualifies that tactical media are overwhelmingly the media of campaigns rather than of broadly based social movements and are rooted in local initiatives with their own agenda and vocabulary (Lovink 2002:255). It provides both the art of getting access and disappearing at the right moment creating new forms of visibility and ephemerality. A central use of the Internet is to distribute 'tools' and in so doing it encourages people to initiate their own actions, their own events and to become producers and distributors of their own new media and their own meanings.

Clemencia Rodriguez (cf. Meikle 2003:11-12) uses the term 'citizen's media' to evoke a concept which moves beyond the reductive binaries of the 'mainstream media' or 'alternative media' where there is a participant-centered approach suggesting we examine such media projects 'in terms of the transformative processes they bring about within participants and their communities.' For Rodriguez, citizen's media provides a platform for people to reclaim a space of expression and to re-narrativize or re-temporalise events.

Hebdige (1979:90-92; cf. Kahn and Kellner 2003) discusses subcultures as a form of 'noise' capable of jamming dominant media transmissions. Hebdige contends that 'alternative subcultures strive to capture media attention and in doing so become involved in the Janus-faced process of attempting to transform dominant codes even as they become appropriated, commodified, and re-defined by the hegemonic culture which they contest.' In applying this notion to the Internet, Kahn and Kellner (2003) point out.

Internet subcultures seek a certain immediacy of experience that strives to circumvent dominant codes in the attempt to access a wealth of global information quickly and directly, and then to appropriate and disseminate material further. 
They argue that Internet subcultures as alternative cultures and practices to the dominant established society are often constructed within and against the dominant culture into which they are born. It is this intertextuality between the inherent dominance and resistance that is often characteristic of Internet subcultures. Such resistance appropriates the semantic codes of the dominant culture by which groups attempt to transmit and reproduce themselves. Such alternative expressions on the Internet, Kahn and Kellner (2003) contend, represent 'a challenge to this symbolic order in their attempt to initiate new grammars and meanings through which they interpret the world and new practices through which they transform it.'

The intertextuality between dominance and the resistance that can thrive in spaces of alternative expression was evident in the staging of the city for the IMF/WB meetings.

In its endeavor to welcome the IMF/WB delegates to Singapore, Prime Minister Lee Hsien Loong urged the citizens to send in images of smiling faces as the country hoped to 'greet the delegates with four million smiles'[8]. The four million smiles campaign however turned into four hundred frowns when a local activist started a campaign to protest against the meeting and to show the world that Singaporeans too are attuned to global issues. Besides the protest of ' 400 frowns', another four million frowns campaign was started online requesting Singaporeans to send in their frowning images. Both these campaigns revealed that new technologies on the Internet were creating a parallel reality where the city-state of Singapore was being narrated in a different light compared to the official monologue of the authorities. The city assumed a dual personality where the government's discourse was mediated and countered through the electronic environment. It demonstrated that the city-state is a site for multiple struggles and contestations, where information and communication technologies create counter sites which re-imagine the city as a space of protest despite stringent laws to curb protest and civil society organizations.

\section{The Internet as a Platform for Resistance}

In June 2006, the Singapore press reported that the authorities were planning to crack down on any signs of dissent in the public through the installation of nearly 158 closed-circuit television (CCTV) cameras to monitor activity at 67 traffic intersections and at the meeting's venue.[9] The combination of pervasive monitoring technology and the ongoing government narrative of order and security again reiterated the emphasis for visual order in the city. Nevertheless, the wiring of the city through new forms of information and communication technologies makes it amenable to alternative voices especially in online spaces where the convergence of technologies have enabled a mediated, visual and discursive pluralism to emerge and to reconstruct a city as a counter-space for protesting against the official discourse.

Technopolitics in the cityscape of Singapore is constantly altered through regulatory environments. Prior to the general election in May 2006, the government imposed new restrictions on online discourse by clamping down on political blogs. The government declared that it is 'illegal to propagate or promote or circulate political issues' in election periods.[10] Despite this, there were 50 web sites and blogs producing political or semi-political content during the election, according to the Institute of Policy Studies. When a blogger (under the pseudonym of Mr. Brown) who wrote a column in a Singapore newspaper was censored for his criticism of government policies, thirty people gathered to protest against the ban. In Aug 2005, a protest by four activists in the business district was broken up by a team of riot police when the protestors called for greater transparency in state institutions after a scandal involving a government-linked charity.[11] Such expressions of protest both online and offline provide an alternative construction of the ordered and homogeneous city space which the authorities attempt to project.

Seelan Pillai, who organized the 400 frowns campaign to counter the Singapore government's four million smiles project and to protest against globalization, was arrested along with two other men and was detained by the authorities. Their computers were seized and the authorities considered charging the men under the Printing and Processing Materials Act under which persons possessing material which contain 'any incitement to violence or counseling disobedience to the law may be jailed for up to three years or fined or both.'[12] Local reaction to the government's ban on protests took various guises, mainly in the online medium where numerous websites and blogs kept an ongoing commentary of the activities which were being blocked by the authorities. Independent sources on the Internet, in comparison to the print and broadcast media monopolized by the government, presented a counterdiscourse, issuing information about attempted rallies and civic actions which were stopped by the police while they were taking place.[13]

These online spaces enable dissenting voices to use new broadcasting technologies such as YouTube to broadcast 
videos and to narrate events which do not appear in the government-owned media archives. These alternative media spaces are recording and narrating both online and offline activities which have been blocked by the authorities. The hypermodernity of the island has seen the emergence of numerous electronic spaces which provide an ongoing commentary of the government's actions and policies and construct the events and protests banished by the government via new technologies as they emerge on the streets. For example, a recent 'Empower' rally organized by the Singapore Democratic Party was blocked by the authorities but narrated online through pictures using these broadcast technologies. Similarly, during the recent general election, despite a ban on broadcasting election rallies online, various blogs carried commentaries and live broadcasts of opposition rallies which were poorly covered by the local government papers. These online discourses as virtual heterotopias are embedded in the social practices of the city and hence they create social spaces which construct the city as one which is plural and politically charged. Additionally, the intrusion of the world media on the events leading up to and during the summit also crafted the city in different ways from the image-event conceived by the government.

\section{Conclusion}

The hosting of the IMF/WB meetings threw the spotlight on a city which is ordered yet fissured, where pluralism and divergent views are emerging in spaces not sanctioned or created by the government. The online medium, while mediated by new forms of regulations and surveillance, cannot be completely controlled or subsumed by government machinery. These virtual spaces constantly mediate the construction of a physical geographical site through their discursive formations, producing space which in many ways is a reaction to the official politics and policies of those in power. They represent new ways of imagining the city space while being the product of the dominant culture themselves. In a space where traditional media are tightly regulated they signify new visibilities and new forms of meaning construction which widen the 'political' beyond the ambit of dominant or hegemonic constructions.

\section{Acknowledgements}

I'd like to express my sincere gratitude and thanks to Ben Agger for his comments, support and helpful suggestions with this paper.

\section{Endnotes}

1. "Singapore Takes flak for Ban on Protests." Straits Times, September 10,2006.

2. "Shift on IMF activities.", September 15, 2006. BBC News website (http://news.bbc.co.uk/2/hi/asiapacific/5348134.stm) (Retrieved 14/11/06).

3. Singapore Government Press Statement 2006. Available; (http://app.sprinter.gov.sg/data/ pr/20060914980.htm) (Retrieved 14/11/06)

4. Activist barred from protesting IMF summit, Political Gateway website, UPI, September 16, 2006, (http://www.politicalgateway.com/news/read/36705) (Retrieved 17/10/06)

5. "Security Stepped up in Singapore ahead of Major IMF Conference," Deutsche Presse Agentur August
30, 2006. (http://asia.news.yahoo.com/060831/32p8go. html) (Retrieved 14/09/2006)

6. Prime Minister and his father sued Far Eastern Economic Review "Reporters without Borders Urges World Bank and IMF Heads to intervene." September 15, 2006, Reporters without Borders website, (http:// www.rsf.org/article.php3?id_article=18882) (Retrieved $10 / 11 / 06)$

7. Sara Webb, "Singapore Media Controls Clash with Regional Aims," Reuters, September 1, 2006, .The Five Publications are Far Eastern Economic Review, Time, Newsweek, Financial Times and the International Herald Tribune.

8. "Singapore to go the Extra Smile for IMF Summit," June 12, 2006, Antara News (http://www.antara.co.id/ 
en/seenws/?id=14198) (Retrieved 13/11/06)

9. Marwaan Macan-Markar ,'World Bank Finds Refuge in Nanny State," July 14, 2006 (IPS) Asia Media Forum websites, (http://www.asiamediaforum.org/node/480) (Retrieved 12/11/06)

10. Sara Webb, "Singapore Media Controls Clash with Regional Aims." Reuters, September 1, 2006.

11. "Singapore Opposition Firebrand Vows IMF Protest." Reuters Aug 312006
12. "Singapore: Where Frowning upon Globalization Gets you Arrested." Indymedia website, (http://www.indymedia.org.uk/en/2006/09/350767. html) (Retrieved 10/11/06)

13. (http://singabloodypore.blogspot.com/2006/09/ empower-singaporeans-rally-march.html).

\section{References}

Berners-Lee, T. 1999. Weaving the Web. Orion: Oxford.

Bircham, E. and J. Charlton, eds. 2000. Anti-Capitalism: A Guide to the Movement. Bookmarks: London.

Bove, J. and F. Dufour. 1999. The World is Not for Sale. Verso: London.

Burton, J. “Singapore Threatens to Cane Violent IMF Protesters.” Financial Times, September 9, 2006. Retrieved November 14, 2006

(http://search.ft.com/searchArticle?queryText=imf+singapore $\& y=4 \&$ javascriptEnabled $=$ true $\& i d=060118000792$ $\& \mathrm{x}=16)$.

Castells, M. 1996. The Information Age: Economy Society and Culture. Vol 1: The Rise of the Network Society. Oxford: Blackwell.

Cohen, S. 1979. "'The Punitive City": Notes on the Dispersal of Social Control' Contemporary Crisis 3(4):339-63.

Coleman, R. 2005. 'Surveillance in the City: Primary Definition and Urban Spatial Order, Crime Media Culture 1(2):131-148.

Deleuze, G. 1997. "Postscript on the Society of Control." In Rethinking Architecture: A Readier in Cultural Theory, edited by Neal Leach. London: Routledge.

Deluca, K.M. and J. Peeples. 2002. "From Public Sphere to Public Screen: Democracy, Activism and the 'Violence' of Seattle." Critical Studies in Media Communication 19(2):125-151.

Dobers, P. 2003. "Image of Stockholm as an IT City: Emerging Urban Entrepreneurship.” In New Movements in Entrepreneurship, edited by C. Steyaert and D. Hjorth. Cheltenham: Edward Elgar.

Hojorth, D., B. Johannisson, and C. Steyaert. 2003 "Entrepreneurship as Discourse and Life Style." In The Northern Lights, Organization Theory in Scandinavia," edited by B. Czariawska and G. Sevon. Trelleborg: Berlings Skogs.

Hubbard, P. and T. Hall. 1998. "The Entrepreneurial City and 'New Urban Politics'”. In The Entrepreneurial City: Geographies of Politics, Regime and Representation, edited by P. Hubbard and T. Hall. West Sussex: John Wiley \& Sons.

Hubbard, D.and D. Miller. 2005. "Introduction: Barbarism Inc." Arguments Against G8, edited by G. Hubbard and D. Miller. London: Pluto Press.

Gellner, E. 1983. Nations and Nationalism. Ithaca, NY: Cornell University Press.

George, C. 2001. Air-Conditioned Nation. Singapore: Landmark Books.
Huntington, Samuel P. 1991. The Third Wave: Democratization in the Late Twentieth Century. London: University of Oklahoma Press

Jacobs J. 1961. The Death and Life of Great American Cities. New York: Random House.

Kellner, D. 2001. "Globalization, Technopolitics and Revolution; The West in Crisis: Technology, Reason, Culture." Theora 48(2). (http://www.gseis.ucla.edu/faculty/kellner/essays/globalizationtechnopoliticsrevolution.pdf).

Kahn, Richard and D. Kellner. 2003. "Internet Subcultures and Oppositional Politics." In The Post-Subcultures Reader, edited by David Muggleton. London: Berg Publishers.

Koopmans, R. 2004. "Movements and Media: Selection Processes and Evolutionary Dynamics in the Public Sphere." Theory and Society 33: 367-391.

Lefebvre, H. 1991. The Production of Space. Oxford: Blackwell

Lim, A. 2001. "Intelligent Island Discourse: Singapore's Discursive Negotiation with Technology." Bulleting of Science, Technology and Society. 21(3):175-192.

Lovink, G. 2002. Dark Fiber: Tracking Critical Internet Culture. MIT Press: Cambridge.

Lubbers, E., ed. 2002. Battling Big Business: Countering Greenwash, Infiltration and Other Forms of Corporate Bullying. Scribe Publications: Melbourne.

Lynch, K. 1960. Image of the City. Cambridge MA: MIT Press. Macan-Markar, M. "Singapore: World Bank Finds Refuge in Nanny State.” IPS, Jul 31 2006, Asia Media Forum. Retrieved November 10, 2006 (http://www.asiamediaforum.org/ node/480).

Mayo, M. 2005. Global Citizens: Social Movements and the Challenge of Globalization. London: Zed.

McMichael, P. 2000. "Sleepless in Seattle: What is the WTO about?" Review of International Political Economy 7(3):466-74.

Meikle, G. 2002. Future Active: Media Activism and the Internet. Routledge: London

Meikle, G. 2003. "We Are All Boat People: A Case Study in Internet Activism," Retrieved November 10, 2006 (http:// www.digitaleskimo.net/downloads/bp_meikle_case_study. pdf)

Meng, S. 2006 "An Impending Crisis to Our Singapore Reputation from Offending the International CSO?"' Singapore Angle 18 Sept. Retrieved April, 26, 2007 (http://www.Sinaporeangle. com/2006/06/impending-crisis-to-our-singapore.html). 
O’Brien, R., A.M. Goetz, J. Scholte, and M. Williams. 2000. Contesting Global Governance: Multilateral Economic Institutions and Global Social Movements. CUP:New York.

Rodan, G. 2006 “Singapore's Founding Myth Vs. Freedom.” Far Eastern Economic Review, October 2006. Retrieved April 26, 2007 (http://www.feer.com/articles1/2006/6010/free/p013. html).

Reporters without Borders Website, Press Freedom Index. 2006. Retrieved November 14, 2006 (http://www.rsf.org/rubrique. php3?id_rubrique $=639$ ).

Sayer, A. 2000. Realism and Social Science. London: Sage.

Scalmer, S. 2002. Dissent Events: Protest, the Media and Political Gimmick in Australia. UNSW Press:Sydney.

Smith. 2001. "Globalizing Resistance: The Battle of Seattle and the Future of Social Movements." Mobilzation 6(1):1-19.

Soja, E. 2000. Postmetropolis: Critical Studies of Cities and Regions. Oxford: Blackwell.

Stayaert, C. and J. Katz. 2004. "Reclaiming the Space of Entrepreneurship: Geographical Discursive and Social Dimension." Entrepreneurship and Regional Development 16(3):179-196.
Tarrow, S. and D. Della Porta. 2005. "Conclusion." In Transnational Protest and Global Activism, edited by D. Della Porta and S. Tarrow. Lanharn: Rowman and Little:121-147.

Tschumi, B. 1996. Architecture and Disjunction. Cambridge, MA: The MIT Press.

Urry, J. 1995. Consuming Places. London: Routledge

Virilio, P. 1986. Speed and Politics: An Essay on Dromology. Translated by Mark Polizotti. New York: Semiotext $(\mathrm{t})$ Foreign Agents Series.

Wee, CJW-L. 2001. “The End of Disciplinary Modernisation? The Asian Economic Crisis and the Ongoing Reinvention of Singapore." Third World Quarterly 22(6):987-1002.

Wilson J. and G. Kelling. 1982. "Broken Windows: The Police and Neighbourhood Safety." Atlantic Monthly 249(3):29-38.

Zukin et al. 1998. "From Coney Island to Las Vegas in the Urban Imaginary: Discursive Practices of Growth and decline." Urban Affairs Review 33(5):627-654. 
